\title{
Regulating the Management of State-Owned Plantations to Improve Public Welfare
}

\author{
Nurpanca Sitorus ${ }^{1}$, Budiman Ginting ${ }^{2}$, Sunarmi $^{3}$, Mahmul Siregar $^{4}$ \\ \{pancastr@gmail.com ${ }^{1}$, budiman_ginting59@yahoo.com ${ }^{2}$, sunarmi@usu.ac.id ${ }^{3}$, \\ mahmuls@yahoo.co.id $\left.{ }^{4}\right\}$ \\ Universitas Sumatera Utara, Indonesia ${ }^{1,2,3,4}$
}

\begin{abstract}
The plantation industry cluster plays an important and strategic role in national development, especially in improving the prosperity and welfare of the people, increasing foreign exchange reserves, providing employment, maintaining value and competitiveness, meeting domestic consumption and industrial raw material needs, and managing natural resources sustainably. The government manages natural resources through state-owned enterprises as regulated in Law 19 of 2003 concerning State-Owned Enterprises. Since the issuance of Government Regulation Number 72 of 2014, PT Perkebunan Nusantara III has become the holding company of PTPN I, II, IV, to XIV. This is normative juridical research that is prescriptive and uses the statute and conceptual approaches. Data is sourced from primary, secondary, and tertiary legal materials, which are analyzed qualitatively. This study indicates that state-owned plantations conduct activities on a substantial amount of land to provide the most significant benefit for the people. As stated in both the preamble and Article 33 of the 1945 Constitution, the State's goals align with this indication. The objective to improve public welfare is on equal priority with obtaining profits. The management of state-owned plantations is regulated in several laws and regulations with the same goal, namely realizing the State's responsibility to improve public welfare.
\end{abstract}

Keywords: Management, Public, State-Owned Plantations, Welfare

\section{Introduction}

State-owned enterprises (SOEs) are closely related to public welfare; the State utilizes them to realize this goal. Therefore, the objectives of SOEs are determined by taking into account their nature as business entities, namely to generate profits and provide public benefits. Therefore, SOEs are classified into limited liability companies (Persero), which aim to generate profits and fully comply with the Limited Liability Company Law provisions, and public companies (Perum), which aim to provide specific goods and services to meet the needs of society.

The State was formed to ensure the physical and mental well-being of all its citizens [1]. The Republic of Indonesia 1945 Constitution states that Indonesia was formed to improve public welfare, educate the people, and establish a world order based on freedom, perpetual peace, and social justice. The preamble to the 1945 Constitution, which is manifested in the articles of the state constitution, contains the objectives of the Indonesian State, namely the realization of economic and social welfare. Based on this provision, the management and control of the land, waters, and natural resources contained therein must be aimed to maximize public welfare. 
Natural resources are managed by SOEs as regulated in Law Number 19 of 2003 concerning State-Owned Enterprises. Paradigmatically, SOEs are an extension of the State's hand in managing the lives of its citizens. The land, the waters, and the natural resources within should be used to the most significant benefit of the people. Therefore, the goal of SOEs is to become economic actors that embody Article 33 Paragraph (3) of the 1945 Constitution [2]. The role of SOEs varies widely among countries, as they are closely related to the country's economic system. In addition, SOEs are political and economic entities. As the government owns them, SOEs are subject to the policies that apply, even if they conflict with one another [3].

Currently, SOEs are categorized into several industrial clusters: energy, oil, and gas; mineral and coal; insurance and pension funds; plantation and forestry; telecommunications and media; food and fertilizer; tourism and support; health; manufacturing; infrastructure; logistics; and financial. The plantation and forestry industry cluster consists of PT Perkebunan Nusantara (PTPN) III as the holding company of PTPN I, II, IV to XIV and Perum Perhutani. This paper will focus on the plantation industry cluster. The plantation industry cluster plays an important and strategic role in national development, especially in improving the prosperity and welfare of the people, increasing foreign exchange reserves, providing employment, maintaining value and competitiveness, meeting domestic consumption and industrial raw material needs, and managing natural resources sustainably.

Plantations are constantly faced with various challenges, issues, changes, and developments in a very dynamic environment as well as various fundamental problems such as globalization and market liberalization; rapid advances in technology and information; increasingly limited land; water and energy resources; climate change; land ownership; the limited capacity of the national seed system; limited capital of smallholders; limited institutional capacity of farmers and trainers; the decline in smallholder productivity; and the lack of coordination between sectors related to plantation development [4].

Referring to the various problems described above, it can be said that state-owned plantations have not been successful in providing the most significant benefit for the people. In theory, the vast natural resources of Indonesia, especially its commodity crops, have a sizeable strategic potential and should be able to be utilized to fulfill this goal. This research aims to answer the following problems based on the description: First, how are state-owned plantations managed? Second, what is the State of public welfare concerning the goal of state-owned plantations?

\section{Research Method}

This is normative juridical research analyzing the management of state-owned plantations for the most significant benefit of the people. Normative research is also called doctrinal legal research. This research conceptualizes law as written in-laws and regulations (law in books) or as rules or norms as benchmarks for appropriate human conduct. This research is prescriptive; it studies the objectives of the law, the values of justice, the validity of the rule of law, legal concepts, and legal norms. This research utilizes statute and conceptual approaches, which examine all laws and regulations related to the research problems and depart from the views and doctrines in law science and analyze them qualitatively. 


\section{Results and Discussion}

\subsection{Management of State-Owned Plantations}

Article 33 Paragraphs (2) and (3) of the 1945 Constitution contain the philosophy and reasoning of why SOEs are formed. Paragraph (2) states that sectors of production that are important for the country and affect the life of the people shall be under the powers of the State. In contrast, Paragraph (3) claims the land, the waters, and the natural resources within shall be under the powers of the State and shall be used to the most significant benefit of the people. These paragraphs infer that the State forms business entities to meet all the needs of society in sectors that the private sector has not handled. This is realized in the creation of SOEs as agents of development. SOEs are classified into public companies (Perum) and LLCs (Persero). Both public and limited liability SOEs are structured as LLCs, with the critical difference being the capital divided into shares, in which $51 \%$ belong to the State. Therefore, limited liability SOEs are not legal entities; the State owns them through shares [5].

As independent legal entities, limited liability SOEs explicitly separate the management of the company and the power of its owners, which is also reflected in the LLC Law in Indonesia. Indonesia adopts a civil law legal system. Attractive trade deals and development programs force a country to meet international standards. A separate legal entity is one example of legal transplantation from the Netherlands to Indonesia, which once colonized Indonesia. However, colonialism was not primarily concerned with legal transplants but rather with conquest [6].

Plantation SOEs are managed as LLCs. Article 11 of Law Number 19 of 2003 concerning State-Owned Enterprises states that all provisions and principles of LLCs apply to limited liability SOEs as stipulated in Law Number 40 of 2007 concerning LLCs. In Bahasa Indonesia, limited liability company is translated to 'perseroan terbatas', consisting of two words: perseroan and terbatas. Perseroan refers to the capital of an LLC, which consists of 'serosero' or shares. Meanwhile, terbatas refers to the responsibility of shareholders whose extent is limited to the nominal value of the shares they own. One of the principles in Law Number 40 of 2007 concerning LLCs is the separation of company assets from their owners. SOEs are business entities whose capital is wholly or principally owned by the State through restricted state assets. In this case, restricted state assets originate from the state budget used as capital for limited liability, public SOEs, and other LLCs. Further financial development and management will be based on sound corporate principles [7].

PTPN III manages all state-owned plantations in Indonesia. The Government has issued Regulation Number 72 of 2014 concerning the Addition of State Equity Participation of the Republic of Indonesia to the Capital Stock of PT Perkebunan Nusantara III. The regulation states the reduction of shares from $90 \%$ to $10 \%$. As a result, PTPN III has become the holding company for PTPN I, II, IV, to XIV. As the holding company, PTPN III owns $90 \%$ of PTPN I, II, IV to XIV shares, while the State owns the remaining 10\%. The current legal framework for establishing a state-owned holding company refers to Government Regulation Number 72 of 2016 concerning Amendments to Government Regulation Number 44 of 2005 concerning Procedures for Participation and Administration of State Equity in State-Owned Enterprises and Limited Liability Companies. The preamble to Government Regulation Number 72 of 2016 explains that establishing a plantation holding company increases the value and optimizes SOEs' role as national development agents in supporting and accelerating government programs.

The essential obligation of corporate management is to maximize profits and ensure longevity by balancing the competing demands of various stakeholders. The provisions of Article 5 Paragraph (3) and Article 6 Paragraph (3) of Law Number 19 of 2003 concerning 
State-Owned Enterprises have adopted several principles of good corporate governance regarding the management of SOEs [8]. Of the various regulations and arrangements related to the administration of plantations above, starting from the SOE Law, the Plantation Law, and the Agrarian Law, it can be concluded that the main objective of the State in managing national wealth is to provide the most significant benefit to the people. Meanwhile, LLCs' objectives can be seen in its articles of association that are based on the will of the company founder. As stateowned plantations are classified as limited liability SOEs, the objective to improve public welfare is on equal priority, intending to obtain profits.

\subsection{Public Welfare as a Goal for State-Owned Plantations}

The fundamental goal of national development is to improve public welfare. This is the constitutional duty of all government and private nation components, as mandated and regulated in the Preamble and Article 33 of the 1945 Constitution. To achieve this goal, overall national economic forces are tightened through sectoral regulations or state ownership of specific business units to benefit the people. SOEs are the pillar of the nation's economy; they are involved in various sectors that play a significant role in realizing the State's goals. The plantation sector is one of the most crucial and strategic sectors that SOEs are involved in, considering the scope of its work which utilizes a tremendous amount of land spread throughout Indonesia. State-owned plantations utilize enormous land and labor force among all SOEs today, which explains the number of people living near plantations [9]. However, there are still many conflicts in both state and private plantation operations. This is mainly due to the unsuccessful attempts to improve public welfare.

The use of land, waters, and skies (as well as the wealth contained therein) for the greatest prosperity of the people is a statement that needs to be more concrete. This means that (1) every designation, use, supply, and maintenance of land, waters, and skies, and (2) every designation and regulation of the relationship between people and the land, waters, and skies (as well as the wealth contained therein) must be used to the most significant benefit of the people [10].

Plantations are established to improve the welfare and prosperity of the people; increase foreign exchange reserves; provide employment and business opportunities; increase production, productivity, quality, value, competitiveness, and market share; increase and fulfill national consumption and industrial raw materials needs; protect plantation owners and the community; manage and develop plantation resources optimally, responsibly, and sustainably; and increase the utilization of plantation services.

The State must improve public welfare. For this reason, the government is required to resolve all problems relating to the lives of its citizens. The Welfare State concept aims to create general welfare. A state is a tool formed by its people to achieve common goals, namely prosperity and social justice. Kranenburg considers the Welfare State theory to strive to maintain legal order and the welfare of its citizens. As welfare covers a wide range of fields, the State's goals are also broad in scope [11].

Public welfare is traditionally understood as the responsibility of society that is fulfilled through the government. This is realized in state administration or government, commonly known as a welfare state [2]. The relationship between the state and natural resources is regulated in Article 33 Paragraph (3) of the 1945 Constitution, which states that the land, the waters, and the natural resources within shall be under the powers of the State and shall be used to the most significant benefit of the people. In this case, state functions are carried out by SOEs. State-owned plantations are an extension of the State's hand in realizing its goal, namely the prosperity of its people. 
According to the constitutional court, the phrase 'under the power of' must be interpreted broadly derived from the conception of the sovereignty of the Indonesian people's overall sources of wealth: the land, the waters, and the natural resources within. This includes public ownership over the wealth sources, as mentioned above. Therefore, the concept of 'under the power of' cannot be interpreted as ownership solely within the framework of civil law [8].

In addition, the land utilized by state-owned plantations is subject to Article 2 of Law Number 5 of 1960 concerning Basic Agrarian Principles. It explicitly states that their authority is derived from the State's right to manage land, waters, and skies, including the natural resources contained therein. All resources shall be used to the most significant benefit of the people, specifically to ensure happiness, prosperity, independence in society, and the Indonesian constitutional State, which is independent, sovereign, and prosperous.

The goals of SOEs are regulated in the SOE Law, which is stated in the preamble of letters $a$ and $b$ of the SOE Law. It requires SOEs to (1) be actors of economic activity in the national economy based on economic democracy and (2) play an essential role in the national economy to realize public welfare. From these two points, it can be concluded that SOEs have two objectives. First, as an extension of the State to achieve the State's goals, SOEs must improve general welfare, which is further elaborated in Article 33 Paragraph (2) and Paragraph (3) of the 1945 Constitution by controlling production branches which are crucial to the State and the livelihood of its people as well as utilizing the land, the waters, and the natural resources. Second, as a business entity, SOEs must obtain profits based on the principles of economic democracy alongside private companies and cooperatives.

The elucidation of SOE Law requires SOEs to contribute to the development of the national economy in general and state revenues in particular. This means that SOEs are expected to improve the quality of service to the community while at the same time contributing to national economic growth and state financial revenues. Furthermore, regarding the objective to obtain profit, the company considers the principles of a healthy company. Therefore, government assignments must be accompanied through financing (compensation) based on business or commercial calculations.

In line with the Constitutional Court Decision Number 12/PUU-XIV/2008, the aims and objectives of SOEs are in line with one of the State's objectives as mandated in the fourth paragraph of the 1945 Constitution's Preamble, namely improving public welfare. This is also in line with the mandate of Article 33 Paragraph (4) of the 1945 Constitution, which states that the organization of the national economy shall be conducted based on economic democracy upholding the principles of togetherness, efficiency with justice, continuity, environmental perspective, self-sufficiency, and keeping a balance in the progress and unity of the national economy without putting aside the essence of the economy as a common endeavor based upon the principles of the family system as emphasized in Article 33 Paragraph (1) of the 1945 Constitution. Therefore, according to the Constitutional Court, the SOEs aims and objectives as stipulated in Article 2 Paragraphs (1) and (2) of the SOE Law are part of an effort to realize the State's goals as emphasized in the preamble and Article 33 of the 1945 Constitution. Therefore, the objectives of SOEs to develop the national economy while seeking profit are constitutional and on equal priority. 


\section{Conclusion}

SOEs are business entities whose capital is wholly or predominantly sourced from the State through restricted State assets. These assets are derived from the State budget to finance stateowned LLCs and public companies, and other LLCs. For example, state-owned plantations are managed as LLCs. Article 11 of Law Number 19 of 2003 concerning State-Owned Enterprises states that all provisions and principles of LLCs apply to limited liability SOEs as stipulated in Law Number 40 of 2007 concerning LLCs. Since the issuance of Government Regulation Number 72 of 2014, PTPN III has become the holding company of PTPN I, II, IV, to XIV. PTPN III holds $90 \%$ of the shares as the holding company, while the State owns the rest.

State-owned plantations are an extension of the State's hand in improving public welfare. State-owned plantations conduct activities on a substantial amount of land to provide the most significant benefit to the people. The objectives of state-owned plantations are regulated in the SOE Law, Plantation Law, Basic Agrarian Law, and LLC Law which can be seen in its Articles of Association, namely realizing the State's responsibility to improve public welfare.

\section{References}

[1] S. H. Puspitasari, "Kontektualisasi Pemikiran Machiavelli tentang Kekuasaan-Tujuan Negara," $J$. Huk. IUS QUIA IUSTUM, vol. 8, no. 18, pp. 30-45, 2001.

[2] B. Manan and S. D. Harijanti, "Artikel Kehormatan: Saat Rakyat Bicara: Demokrasi dan Kesejahteraan," Padjadjaran J. Law, vol. 1, no. 1, 2014.

[3] M. I. Asnawi, "Implikasi Pengelolaan BUMN Persero dalam Kerangka Welfare State berdasarkan Mekanisme Perseroan Terbatas," J. Huk. Samudra Keadilan, vol. 11, no. 1, pp. 126-144, 2016.

[4] D. S. Nugraha and S. Suteki, "Politik Hukum Penanganan Konflik Perkebunan oleh Pemerintah yang Berkeadilan Sosial," Kanun J. Ilmu Huk., vol. 20, no. 1, pp. 103-122, 2018.

[5] I. Fititriani, "Pola Pengelolaan Badan Usaha Milik Negara Sebuah Potret Singkat," Manajerial J. Manaj. dan Sist. Inf., vol. 10, no. 2, pp. 54-75, 2011.

[6] R. E. Freeman, "A stakeholder theory of the modern corporation," Perspect. Bus. Ethics Sie, vol. 3, p. 144, 2001.

[7] N. Pramono, Perbandingan Perseroan Terbatas di Beberapa Negara. Pusat Penelitian dan Pengembangan Sistem Hukum Nasional Badan Pembinaan Hukum Nasional Kementerian Hukum dan Hak Asasi Manusia R.I., 2012.

[8] R. Harun, BUMN dalam sudut pandang tata negara: Privatisasi, holdingisasi, kontrol dan pengawasan. Balai Pustaka, 2019.

[9] C. O. Tharanon, "Reformasi Standar Kesejahteraan Pekerja BUMN Perkebunan dalam Kerangka Negara Kesejahteraan," 2019.

[10] R. Z. Titahelu, Penetapan Asas-Asas Hukum Umum dalam Penggunaan Tanah untuk Sebesarbesar Kemakmuran Rakyat (Suatu Kajian Filsafati dan Teoretik tentang Pengaturan dan Penggunaan Tanah di Indonesia). Deepublish, 2016.

[11] W. R. Effendi, "Konsep Wellfare State Di Indoneisa,” J. Trias Polit., vol. 1, no. 1, 2017. 